\title{
Compatibility Analyses of BICUVOX.10 as a Cathode in Yttria-stabilized Zirconia Electrolytes for Usage in Solid Oxide Fuel Cells
}

\author{
Roger Honorato Piva ${ }^{a *}$, Diógenes Honorato Piva ${ }^{b}$, Marcelo Tramontin Souza ${ }^{c}$, Márcio Raymundo Morelli ${ }^{a}$ \\ ${ }^{a}$ Laboratory of Ceramic Formulation and Synthesis, Postgraduate Program in Materials Science and \\ Engineering - PPG-CEM, Materials Engineering Department - DEMa, Federal University of São \\ Carlos - UFSCar, Rod. Washington Luis, Km 235, CEP 13565-905, São Carlos, SP, Brazil \\ ${ }^{b}$ Laboratory of Ceramic Materials, Federal University of Rio Grande do Sul-UFRGS, Av. Osvaldo \\ Aranha 99, CEP 90035-190, Porto Alegre, RS, Brazil \\ 'Laboratory of Glass-Ceramic Materials, Federal University of Santa Catarina - UFSC, Campus \\ Universitário Reitor João David Ferreira Lima, CEP 88040-900, Santa Catarina, SC, Brazil
}

Received: January 29, 2013; Revised: August 21, 2014

\begin{abstract}
Copper-substituted bismuth vanadate has been considered a promising material for composite cathodes in SOFC. However, high reactivity of BICUVOX.10 towards the electrolytes still has been its greatest shortcoming. This paper describes reactions between BICUVOX.10 and yttria-stabilized zirconia (YSZ) electrolytes. Secondary phases formed were evaluated by X-ray diffraction, scanning electron microscopy and a.c. impedance spectroscopy. A deleterious interaction between BICUVOX.10 and $\mathrm{YSZ}$ was observed, mainly regarding the yttrium depletion from $\mathrm{ZrO}_{2}$ lattice through reaction with $\mathrm{VO}_{2.5}$, resulting in $\mathrm{YVO}_{4}$ phase nucleation and destabilization of the tetragonal and cubic $\mathrm{ZrO}_{2}$ polymorphs to monoclinic. The $\mathrm{ZrO}_{2}$ destabilization and $\mathrm{YVO}_{4}$ nucleation are related phenomena and were interpreted through a theoretical mechanism using charge-compensating dopants description. Thus, these reactions were seen as detrimental to the cathode/electrolyte contact, especially regarding the highly resistive layer formed in the BICUVOX.10/YSZ junction, discouraging further usage of BICUVOX.10 as a cathode in yttria-stabilized zirconia electrolytes.
\end{abstract}

Keywords: BICUVOX.10, YSZ, cathode, destabilization, SOFC

\section{Introduction}

Costs for broad commercialization of solid oxide fuel cells (SOFC) can be considerably reduced by lowering the operation temperature of such devices ${ }^{1-3}$. Nowadays, the process to reduce the operating temperature is still limited by the insufficient oxygen transport across the electrolyte at low temperatures. However, $\mathrm{Xia}$ and $\mathrm{Liu}^{4}$ proposed that a significant reduction in the SOFC operating temperature can be obtained through the development of composite cathodes with higher catalytic activity for oxygen reduction, thereby offering high power densities without exchanging the electrolyte.

A proposed alternative material with high ionic conductivity in such composite cathodes by Xia and $\mathrm{Liu}^{4}$ is copper-substituted bismuth vanadate (BICUVOX.10) (5-7. $^{5-7}$ The ionic conductivity of BICUVOX. 10 at $300{ }^{\circ} \mathrm{C}$ is in the order of $10^{-3} \mathrm{~S}_{\mathrm{cm}}^{-1}$, value almost 100 times greater than any other solid electrolyte at this temperature ${ }^{5-7}$. Considering such BICUVOX.10 feature, significant research has been conducted using this material as a cathode composite together with gadolinia-doped ceria electrolytes (GDC) ${ }^{3,8,9}$. It was found that the interfacial cathodic polarization between the composite cathode BICUVOX.10/Ag and a GDC electrolyte at $500{ }^{\circ} \mathrm{C}$ is of merely $0.53 \Omega . \mathrm{cm}^{2}$, value much

*e-mail: rogerh.piva@ufscar.br lower than those obtained when using $\mathrm{La}_{0.6} \mathrm{Sr}_{0.4} \mathrm{Co}_{0.2} \mathrm{Fe}_{0.8} \mathrm{O}_{3-\delta}$ (LSCF) or $\mathrm{Sm}_{0.5} \mathrm{Sr}_{0.5} \mathrm{CoO}_{3-\delta}$ (SSC) cathodes.

Despite these interesting BICUVOX.10 characteristics, the main problem identified during the application of this material as a cathode is its high reactivity towards the electrolyte. A.J. Samson et al. ${ }^{10}$ observed that the temperature required to achieve a coating with good adhesive characteristics at the junction of BICUVOX.10+LSC(cathode) / GDC(electrolyte) is high enough to allow interfacial reactions, leading to inappropriate ionic transport through the reaction zone in the cathode/electrolyte interface. However - regarding the formed products and their properties - these reaction zones have not been fully examined. Furthermore, it has been reported by Z. Shao et al. ${ }^{11}$ that mixtures of BICUVOX.10 $+\mathrm{Sm}_{0.15} \mathrm{Ce}_{0.85} \mathrm{O}_{1.925}$ (SDC) gave rise to secondary phases formation at $700{ }^{\circ} \mathrm{C}$ with lower electrical conductivity than BICUVOX.10.

In spite of such extensive research in the employment of BICUVOX.10 as a cathode material in doped-ceria electrolytes, there are no studies demonstrating the compatibility of BICUVOX.10 as a composite cathode applied in stabilized zirconia. This paper describes reactions and phase transformations in a modeled interface between BICUVOX.10 and yttria-stabilized zirconia (YSZ), 
focusing on the properties of the secondary phases formed and how such products can influence the performance of BICUVOX.10(cathode) / YSZ(electrolyte)-based devices.

\section{Experimental}

\subsection{Samples preparation}

BICUVOX.10 $\left(\gamma^{\prime}-\mathrm{Bi}_{2} \mathrm{~V}_{0.9} \mathrm{Cu}_{0.1} \mathrm{O}_{5.35}\right)$ was synthetized in a fusion reaction method using stoichiometric amounts of $\mathrm{Bi}_{2} \mathrm{O}_{3}\left(98 \%\right.$, Vetec), $\mathrm{V}_{2} \mathrm{O}_{5}(99.5 \%$, Vetec) and $\mathrm{CuO}$ $(99.8 \%$, Mallinckrodt). In this method, the stoichiometric mixture was heated up to its melting point $\left(900{ }^{\circ} \mathrm{C}\right)$ in a $\mathrm{ZrO}_{2}-\mathrm{Al}_{2} \mathrm{O}_{3}-\mathrm{SiO}_{2}$ crucible for $1 \mathrm{~h}$. Subsequently, the molten mixture was quenched in water at $\sim 0{ }^{\circ} \mathrm{C}$. In order to ensure better homogeneity, this melting $\rightarrow$ water quenching step was repeated. The obtained powders were dry-milled until particle size of $0.65 \mu \mathrm{m}$. More details about this procedure were reported by $\mathrm{H}$. Biz ${ }^{12}$. Commercial yttria-stabilized zirconia powders containing 3 mol. $\% \mathrm{Y}_{2} \mathrm{O}_{3}$ (3Y-TZP; tetragonal) and $8 \mathrm{~mol} . \% \mathrm{Y}_{2} \mathrm{O}_{3}(8 \mathrm{YSZ}$; cubic) were obtained from Tosoh Corp.

In order to evaluate the interfacial reactions, a junction of BICUVOX.10 / 3Y-TZP was developed by placing a dense sample of BICUVOX.10 (95\% theoretical density, average grain size of $3 \mu \mathrm{m}$ ) upon of a 3 Y-TZP dense sample (99\% theoretical density). Both samples were joined by heating to $955^{\circ} \mathrm{C}$ for $2 \mathrm{~h}$ with heating/cooling rates of $5^{\circ} \mathrm{C} /$ min. The temperature of $955^{\circ} \mathrm{C}$ used was experimentally optimized in order to avoid insufficient adhesion of the BICUVOX.10 / 3Y-TZP junction, as previously observed in other systems ${ }^{10}$. Characteristics of the reaction zone at the junction of BICUVOX.10 / 3 Y-TZP were obtained from developing a composition with 50 wt.\% BICUVOX.10+ 50 wt.\% 3 Y-TZP (50B/50Z3), which was mixed in a ball mill for $24 \mathrm{~h}$, compacted under uniaxial pressure of $45 \mathrm{MPa}$ and exposed to the same temperature conditions mentioned above for the junction BICUVOX.10 / 3Y-TZP. Evaluation of the reactions between cubic $\mathrm{ZrO}_{2}$ and BICUVOX.10 was performed replacing the $3 \mathrm{Y}$-TZP with $50 \mathrm{wt} . \% 8 \mathrm{YSZ}$ $(50 \mathrm{~B} / 50 \mathrm{Z} 8)$. However, emphasis was given to the study of reactions in tetragonal zirconia, considering that this polymorph is subject of studies for use as an electrolyte in SOFC at low temperature operation ${ }^{13}$, in which the composite cathodes made of BICUVOX.10 are more appropriate. In addition, during the development of this work, it was observed that a better understanding of the reaction aspects between BICUVOX.10/YSZ is obtained in the evaluation of the tetragonal polymorph.

\subsection{SEM, XRD and impedance measurements}

In order to characterize microstructural changes, the sample 50B/50Z3 was polished and thermally etched at 855 ${ }^{\circ} \mathrm{C}$ for $30 \mathrm{~min}$. In the case of the BICUVOX.10 / 3Y-TZP junction, microstructure of fracture surface was examined without any previous treatment. SEM (FEI Inspect S 50) equipped with an energy dispersive X-ray spectrometer (EDX) was used to determine the chemical composition of the samples. The phases present in the samples were determined by X-ray diffraction (XRD, Siemens model
D5005) using $\mathrm{Cu}-\mathrm{K} \alpha$ radiation, $2 \theta$ range of 20 to $65^{\circ}$ with $0.02^{\circ}$ step. Destabilization extension of the tetragonal $\rightarrow$ monoclinic phase transition in $\mathrm{ZrO}_{2}$ was calculated considering the volume fraction of the formed monoclinic phase $\left(\mathrm{v}_{\mathrm{m}}\right)$, as estimated by Equation $1^{14}$.

$$
\mathrm{v}_{\mathrm{m}}=\frac{1.311 \mathrm{X}_{\mathrm{m}}}{1+1.311 \mathrm{X}_{\mathrm{m}}}
$$

Where $\mathrm{X}_{\mathrm{m}}$ is the integration of the intensities ratio (Equation 2) and I represents the diffraction intensity of the respective lattice plane in subscript.

$$
\mathrm{X}_{\mathrm{m}}=\frac{\mathrm{I}_{\mathrm{m}(\overline{1} 11)}+\mathrm{I}_{\mathrm{m}(111)}}{\mathrm{I}_{\mathrm{m}(\overline{1} 11)}+\mathrm{I}_{\mathrm{m}(111)}+\mathrm{I}_{\mathrm{t}(101)}}
$$

Samples for conductivity were prepared as cylindrical pellets with $1 \mathrm{~mm}$ in thickness and $8 \mathrm{~mm}$ in diameter. $\mathrm{Pt}$ electrodes were placed on the sample as electrical contacts. Impedance spectroscopy measurements were performed in a temperature range of $425-600{ }^{\circ} \mathrm{C}$, frequencies from 1 to $10^{6} \mathrm{~Hz}$ and voltage amplitude of $0.1 \mathrm{~V}$, using a Solartron SI 1260 impedance analyser.

\subsection{Thermal expansion coefficient and tensile strength}

Coefficients of linear thermal expansion $(\alpha)$ were determined using a dilatometer furnace NETZSCH model DIL402C. Sintered cylindrical samples of approximately $6 \mathrm{~mm}$ in length and $8 \mathrm{~mm}$ in diameter were analysed with a heating rate of $5^{\circ} \mathrm{C} / \mathrm{min}$ until $700^{\circ} \mathrm{C}$, and $\alpha$ was obtained between $150-700{ }^{\circ} \mathrm{C}$.

Tensile strength assessment $\left(\sigma_{\mathrm{TS}}\right)$ was performed through diametral compression test ${ }^{15}$ following the Equation 3. Samples of $8 \mathrm{~mm}$ in diameter (D) and $4 \mathrm{~mm}$ in thickness (h) were developed for testing. The tensile strength values shown in this paper are an arithmetic mean from 4 samples. The tests were performed at room temperature in a universal electro-mechanical tester INSTRON series 5500R, with a load cell of $500 \mathrm{~kg}$ and test rate of $0.5 \mathrm{~mm} / \mathrm{min}$ until the maximum force applied before rupture of the specimens take place (F). Data acquisition was performed by the Blue Hill $^{\circledR}$ software.

$\sigma_{\mathrm{TS}}=\frac{2 \mathrm{~F}}{\pi \mathrm{Dh}}$

\section{Results}

As shown in the interfacial junction, Figures $1 \mathrm{a}$ and $\mathrm{b}$, the formation of a reaction zone occurs with height larger than $10 \mu \mathrm{m}$ consisting mainly of $\mathrm{Zr}$ with traces of other elements such as $\mathrm{Bi}, \mathrm{V}$ and $\mathrm{Cu}$. This reaction zone has higher porosity and disorder than the vicinity. X-ray diffraction patterns, Figures 1c-e, show that the sample that simulates the products formed by the reaction conserves the phase $\gamma^{\prime}-\mathrm{Bi}_{2} \mathrm{~V}_{0.9} \mathrm{Cu}_{0.1} \mathrm{O}_{5.35}$. Nevertheless, when comparing the specimen which simulates the reaction zone $(50 \mathrm{~B} / 50 \mathrm{Z3})$ with $3 \mathrm{Y}-\mathrm{TZP}$, it is possible to observe a reduction of intensity of the (101) crystallographic plane of the tetragonal phase and a related increase at the (111) and (-111) peaks of the 


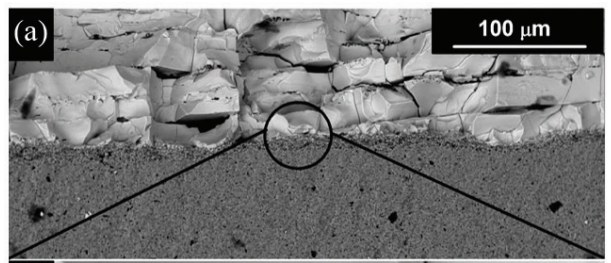

(b)

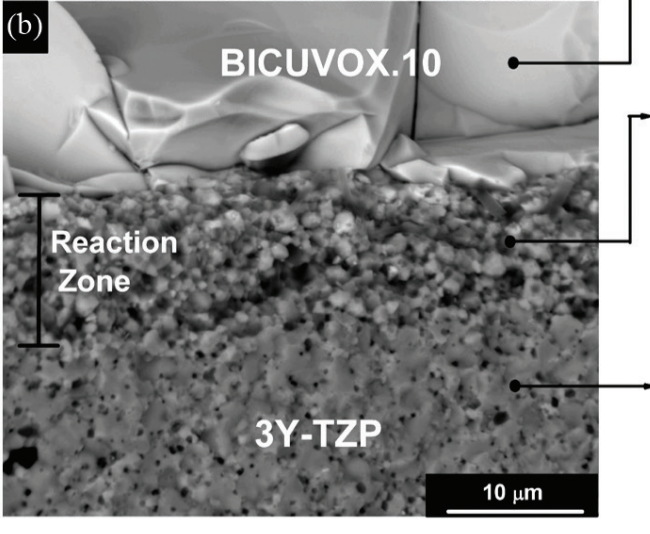

Figure 1. (a) Reaction zone created by interaction between BICUVOX.10 and 3Y-TZP. (b) Reaction zone magnification (5000x) linked to EDX analysis. X-ray diffraction patterns for (c) BICUVOX.10, (d) 50B/50Z3 and (e) 3 Y-TZP. The crystallographic planes used to measure the extent of destabilization are shown in the X-ray diffraction patterns.

monoclinic phase. Hence, the extent of destabilization calculated by the volume fraction of monoclinic phase reached 86 v. $\%$ for the sample $50 \mathrm{~B} / 50 \mathrm{Z} 3$. Furthermore, in the sample $50 \mathrm{~B} / 50 \mathrm{Z} 3$ the destabilization of tetragonal zirconia is accompanied by the formation of yttrium vanadate $\left(\mathrm{YVO}_{4}\right)$, as identified by $\mathrm{X}$-ray diffraction.

Secondary phases formed in the reaction zone are the same found in the $50 \mathrm{~B} / 50 \mathrm{Z} 3$, since they were thermally treated under the same conditions. Observing the $50 \mathrm{~B} / 50 \mathrm{Z3}$ sample in Figure 2, the $\gamma^{\prime}-\mathrm{Bi}_{2} \mathrm{~V}_{0.9} \mathrm{Cu}_{0.1} \mathrm{O}_{5.35}$ phase (white region) settles preferably among the monoclinic zirconia and yttrium vanadate crystals. An excessive growth of prismatic monoclinic $\mathrm{ZrO}_{2}$ crystals, reaching $7 \mu \mathrm{m}$ in length has also been observed. In the case of the sample 50B/50Z8, it is possible to observe by the $\mathrm{X}$-ray diffraction patterns in the Figure 3 that cubic $\mathrm{ZrO}_{2}$ was also destabilized to the monoclinic polymorph. The product originated in the interaction between BICUVOX.10 / 8YSZ was $\mathrm{YVO}_{4}$ - the same phase obtained when reacting BICUVOX.10 and 3Y-TZP.

Figure 4 shows that the thermal expansion coefficient and tensile strength of $50 \mathrm{~B} / 50 \mathrm{Z} 3$ are lower than those found for 3Y-TZP. For instance, as to the tensile strength - which had the most marked reduction - the 50B/50Z3 sample showed one third of the measured resistance of 3Y-TZP. Likewise, the electrical conductivity assessment in $50 \mathrm{~B} / 50 \mathrm{Z} 3$, Figure 5 , shows that the electrical conductivity of such material is lower as compared to BICUVOX.10 and 3 Y-TZP. At $500{ }^{\circ} \mathrm{C}$ the electrical conductivity displayed by $50 \mathrm{~B} / 50 \mathrm{Z} 3$ was of $6.2 \times 10^{-7} \mathrm{~S}^{-\mathrm{cm}^{-1}}$, whereas for BICUVOX.10 it was of approximately $4.6 \times 10^{-2} \mathrm{~S}^{-\mathrm{cm}^{-1}}$. Nevertheless, the activation energy of $1.71 \mathrm{eV}$ found for $50 \mathrm{~B} / 50 \mathrm{Z} 3$ is considerably larger than that for BICUVOX.10, $0.57 \mathrm{eV}$.

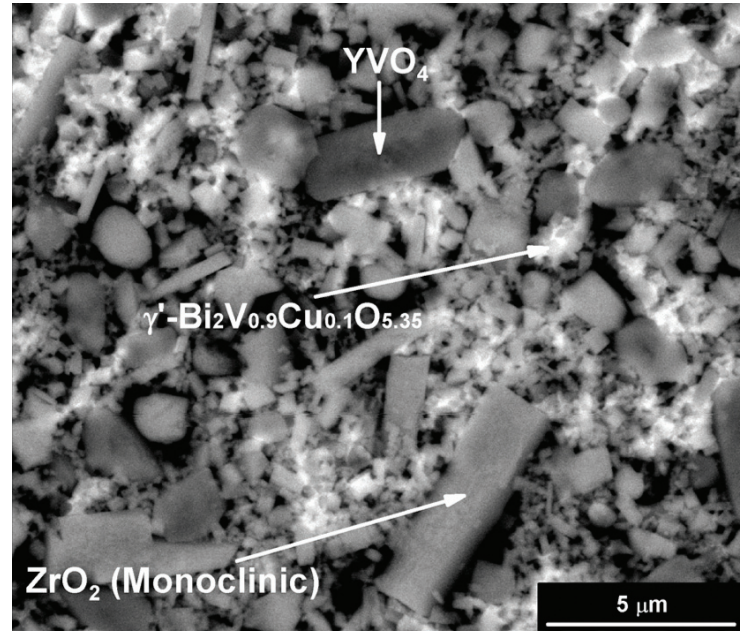

Figure 2. Backscattered electron micrograph of the sample $50 \mathrm{~B} / 50 \mathrm{Z3}$. Phases and products derived from reactions between BICUVOX.10 and 3Y-TZP are indicated by arrows.

\section{Discussion}

As observed in X-ray diffraction, in both 3Y-TZP (Figure 1d) and 8YSZ (Figure 3b), the interaction between yttria-stabilized zirconia and BICUVOX.10 results in high-temperature $\mathrm{ZrO}_{2}$ polymorphs destabilization and $\mathrm{YVO}_{4}$ formation. The production of yttrium vanadate and destabilization of tetragonal/cubic $\mathrm{ZrO}_{2}$ polymorphs can be understood considering the Reaction 4. The $\mathrm{YVO}_{4}$ formation occurs due to the reaction between the $\mathrm{YO}_{1.5}$ stabilizer cation from $\mathrm{ZrO}_{2}$ and $\mathrm{VO}_{2.5}$ from $\gamma^{\prime}$ $\mathrm{Bi}_{2} \mathrm{~V}_{0.9} \mathrm{Cu}_{0.1} \mathrm{O}_{5.35}$. Some studies ${ }^{16,17}$ have shown yttrium 


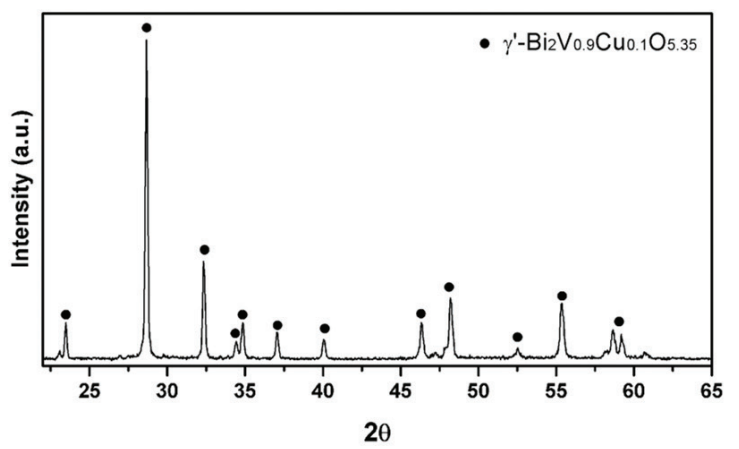

(a)

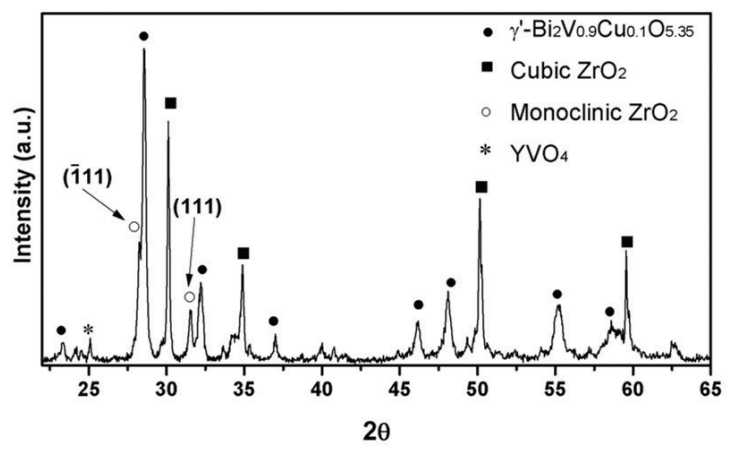

(b)

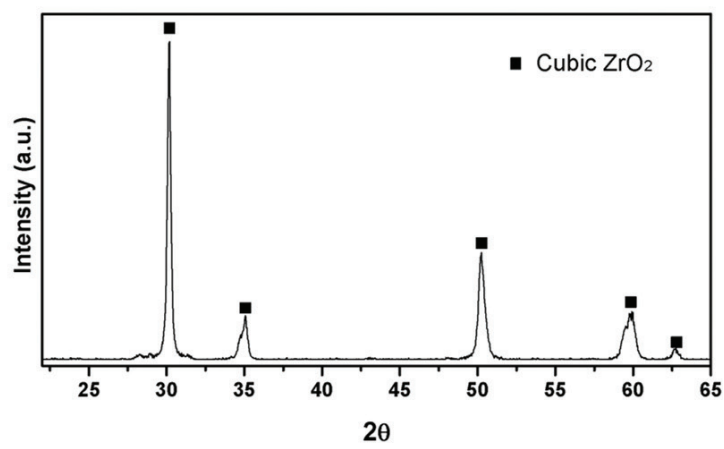

(c)

Figure 3. X-ray diffraction patterns for (a) BICUVOX.10, (b) 50B/50Z8 and (c) $8 Y$ SZ. Crystallographic planes of $\mathrm{ZrO}_{2}$ monoclinic polymorph are shown in (b).

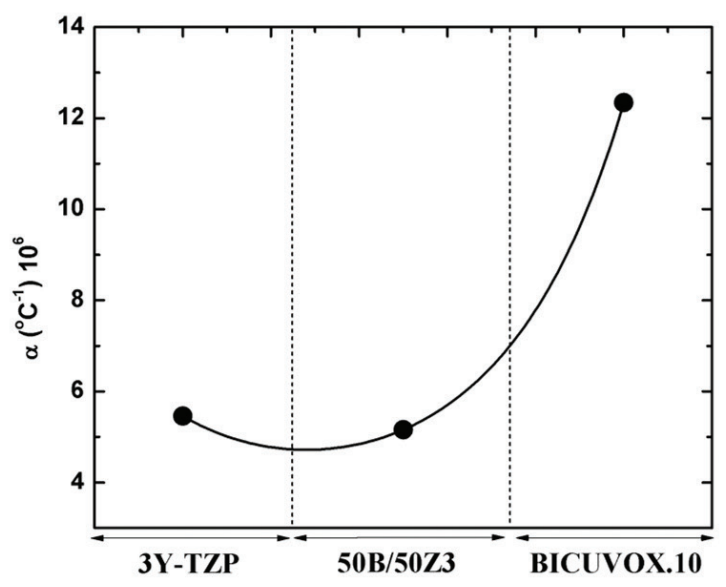

(a)

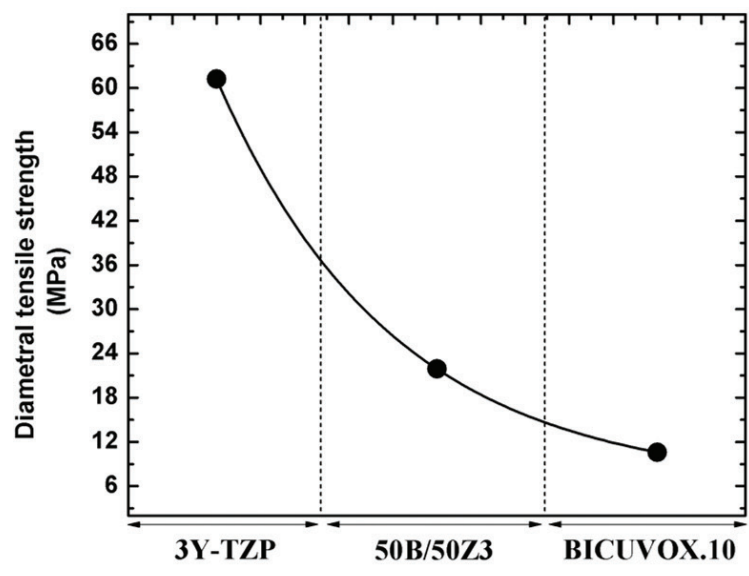

(b)

Figure 4. (a) Coefficients of linear thermal expansion for 3Y-TZP, BICUVOX.10 and 50B/50Z3, which represent the reaction zone. (b) Diametral tensile strength for 3Y-TZP, BICUVOX.10 and 50B/50Z3. Diametral tensile strength graph exhibits only the mean values.

vanadate as a thermodynamically favorable product when vanadia and yttria react (Reaction 5). Hence, $\mathrm{YVO}_{4}$ formation is intimately related to $\mathrm{ZrO}_{2}$ destabilization, since depletion of the stabilizer cation from $\mathrm{ZrO}_{2}$ structure results in the transformation of tetragonal or cubic phase into the most stable $\mathrm{ZrO}_{2}$ polymorph at room temperature, i.e., the monoclinic polymorph. Corrosion studies of YSZ for thermal barrier coatings have shown that zirconia destabilization through the reaction with vanadium does not occur at temperatures below $800^{\circ} \mathrm{C}^{18}$. Notwithstanding, the massive diffusion displayed by the $\mathrm{V}^{5+}$ ions at $800{ }^{\circ} \mathrm{C}$ is sufficient for the nucleation of $\mathrm{YVO}_{4}$ crystals $^{19}$. A.J. Samson et al. ${ }^{10}$ showed that temperatures higher than $800{ }^{\circ} \mathrm{C}$ are crucial to promote adhesion using BICUVOX.10 as cathode for ceria-doped electrolytes. The aforementioned fact indicates that Reaction 4 is of paramount importance 
for this system, since BICUVOX.10 / YSZ-based devices certainly will require high temperatures - or at least, temperatures similar to the ceria-doped case - to promote good adhesive characteristics.

$\mathrm{Zr}_{1-\mathrm{x}} \mathrm{Y}_{\mathrm{x}} \mathrm{O}_{2-0.5 \mathrm{x}}$ (tetragonal or cubic) $+\gamma^{\prime}-\mathrm{Bi}_{2} \mathrm{~V}_{0.9} \mathrm{Cu}_{0.1} \mathrm{O}_{5.35} \rightarrow$ $\mathrm{ZrO}_{2}$ (monoclinic) $+\gamma^{\prime}-\mathrm{Bi}_{2} \mathrm{~V}_{0.9-\mathrm{x}} \mathrm{Cu}_{0.1} \mathrm{O}_{5.35}+\mathrm{xYVO}_{4}$

$\mathrm{YO}_{1.5}+\mathrm{VO}_{2.5} \rightarrow \mathrm{YVO}_{4}$

In order to further understand Reaction 4, a theoretical mechanism was proposed to explain the $\mathrm{ZrO}_{2}$ destabilization using a charge-compensating dopants description ${ }^{19}$. Primarily, the destabilization mechanism is derived from two aspects of the $\mathrm{ZrO}_{2}$ structure; one of them establishes that when $\mathrm{ZrO}_{2}$ co-doping with $\mathrm{M}^{5+}$ and $\mathrm{M}^{3+}$ cations occurs, the negative charge of $\mathrm{M}^{3+} \rightarrow \mathrm{Zr}^{4+}\left(\mathrm{M}_{\mathrm{Zr}}^{\prime}\right)$ substitution will be

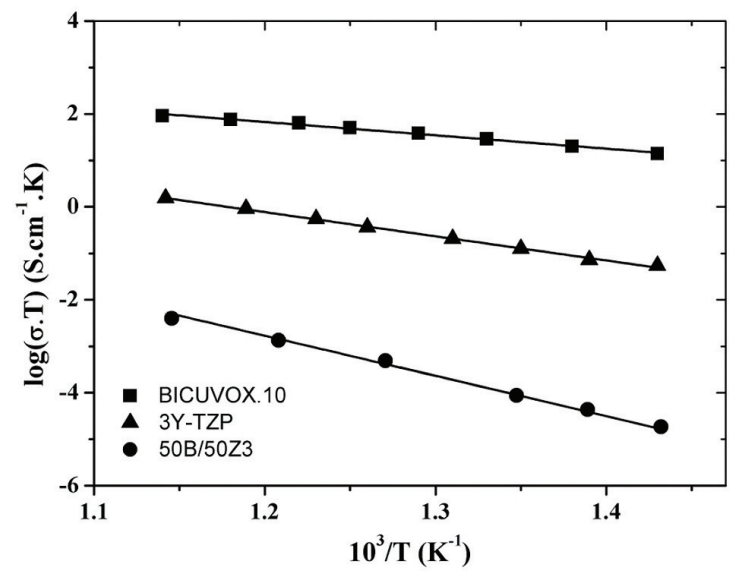

Figure 5. Arrhenius plot for BICUVOX.10, 3 Y-TZP and 50B/50Z3, indicating the effects of reactions and phase transformations in the electrical conductivity. directly compensated by the positive charge generated by $\mathrm{M}^{5+} \rightarrow \mathrm{Zr}^{4+}\left(\mathrm{M}_{\mathrm{Zr}}^{\square}\right)^{19-21}$. Secondly, the ability of tetragonal or cubic $\mathrm{ZrO}_{2}$ polymorphs being stabilized at room temperature arises due to the lower coordination of $\mathrm{Zr}^{4+}$ ions when oxygen vacancies are generated by $\mathrm{M}^{3+}$ doping ${ }^{22}$. Such $\mathrm{ZrO}_{2}$ destabilization model shows the link between the tetragonal or cubic to monoclinic transformation with the $\mathrm{YVO}_{4}$ secondary phase nucleation. As shown in Figure 6 , considering the oxygen vacancies available in the $\mathrm{ZrO}_{2}$ doping with $\mathrm{Y}_{2} \mathrm{O}_{3}(\mathrm{I})$, when $\mathrm{V}^{5+}$ provided by $\gamma$ '$\mathrm{Bi}_{2} \mathrm{~V}_{0.9} \mathrm{Cu}_{0.1} \mathrm{O}_{5.35}$ diffuses into the stabilized $\mathrm{ZrO}_{2}$ lattice, thus replacing the zirconium ions, a consumption of oxygen vacancies initially generated by the yttrium doping (II) takes place. Crystal electroneutrality demands that the charge sum of all point defects must be null. A limitation in the quantity of $\mathrm{V}^{5+}$ in the $\mathrm{Zr}^{4+}$ positions occurs since $\mathrm{V}^{5+} \rightarrow \mathrm{Zr}^{4+}$ replacement occurs only while oxygen vacancies exist, converging to the same concentration $\left[\mathrm{Y}_{\mathrm{Zr}}^{\prime}\right]=\left[\mathrm{V}_{\mathrm{Zr}}^{\square}\right]$. When this equimolarity for the two cations is reached (III), all the oxygen vacancies generated by $\left[\mathrm{Y}_{\mathrm{Zr}}^{\prime}\right]$ are consumed by $\left[\mathrm{V}_{\mathrm{Zr}}^{\square}\right]$. Consequently, the oxygen vacancies responsible for the initial stabilization of tetragonal or cubic polymorphs are extinct and the precipitation of $\mathrm{YVO}_{4}$ from stabilized $\mathrm{ZrO}_{2}$ takes place.

Although the $\mathrm{YVO}_{4}$ formation is derived only on the diffusion from $\mathrm{V}^{5+}$ ions into the zirconia lattice, the effect of liquid BICUVOX.10 should play a significant role in this mechanism. As bismuth vanadate solid solutions undergo incongruent melting at $880^{\circ} \mathrm{C}^{23}$, some solution-precipitation reaction could occur at temperatures higher than that, therefore, accelerating interfacial reactions between BICUVOX.10 and YSZ. Moreover, temperatures above of BICUVOX.10 melting point also result in excessive grain growth. As shown in Figure 1a, BICUVOX.10 grains of originally $3 \mu \mathrm{m}$ reach almost $100 \mu \mathrm{m}$ after reaction tests at

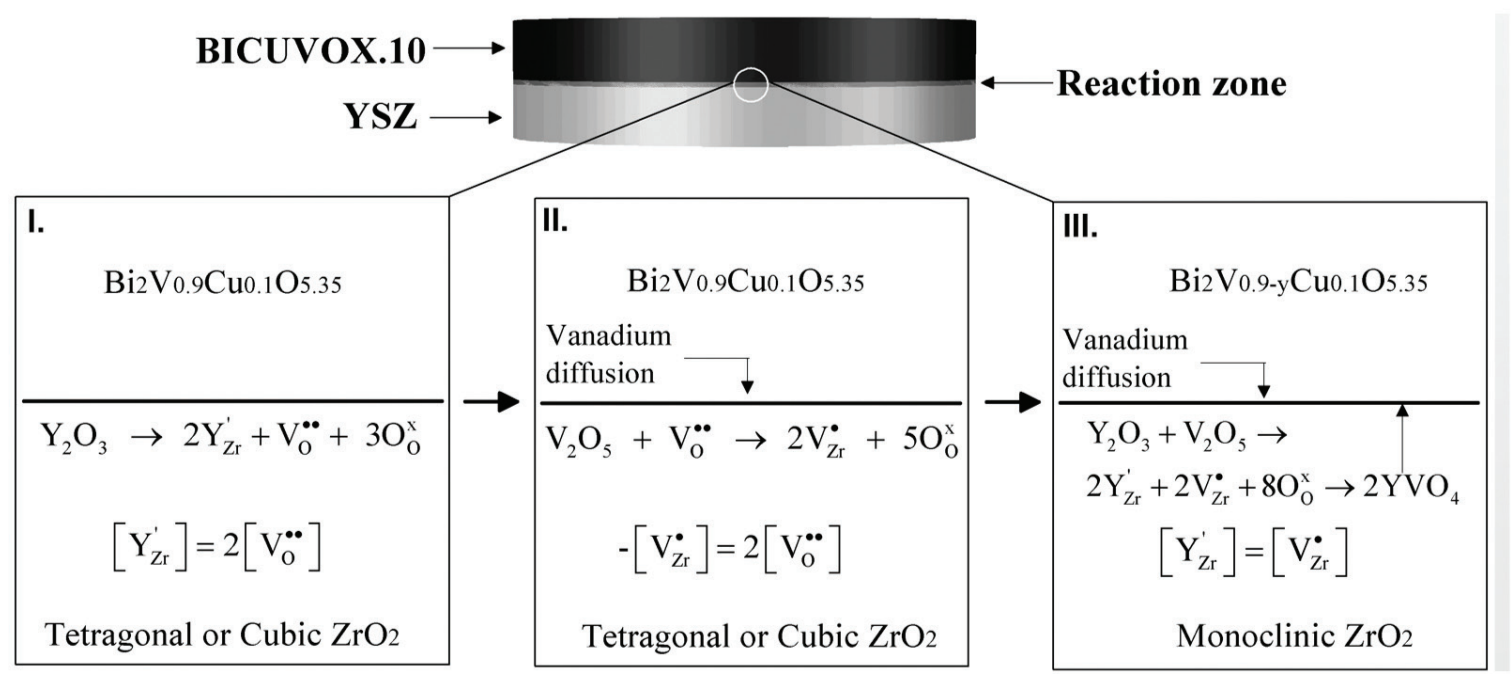

Figure 6. Proposed mechanisms for high-temperature $\mathrm{ZrO}_{2}$ polymorphs destabilization and $\mathrm{YVO}_{4}$ nucleation. This charge-compensating dopants description mechanism is explained into three main steps. The Kröger-Vink notation for the $\left|\mathrm{V}_{\mathrm{Zr}}^{\square}\right|$ defect may be confusing, because the $\mathrm{V}$ symbol, which represents vanadium ion, has always been applied to describe a vacancy defect. However, in this schematic representation, $\left[\mathrm{V}_{\mathrm{Zr}}^{\square}\right.$ ] represents one $\mathrm{V}^{5+}$ ion replacing the $\mathrm{Zr}^{4+}$ cation into the $\mathrm{ZrO}_{2}$ lattice. 
$955^{\circ} \mathrm{C}$. This same effect was previously reported by A.J. Samson et al. ${ }^{10}$.

As seen in the properties of $50 \mathrm{~B} / 50 \mathrm{Z} 3$ sample, the $\mathrm{YVO}_{4}$ formation and $\mathrm{ZrO}_{2}$ destabilization have brought strong influences in the junction behaviour. The low thermal expansion coefficient and tensile strength of the $50 \mathrm{~B} / 50 \mathrm{Z} 3$ sample in relation to $3 \mathrm{Y}$-TZP are originated from highly disordered and defect-rich regions when the reactions showed in Reaction 4 take place. Considering the destabilization mechanism proposed in this paper, the volumetric expansion caused by the transition from tetragonal to monoclinic $\mathrm{ZrO}_{2}$ and $\mathrm{YVO}_{4}$ crystal growth is responsible for the highly disordered region observed in the reaction zone. These interfacial defects act as points of high stress concentration, leading to the deterioration of the mechanical strength seen in the 50B/50Z3 sample.

Although it has been shown that reaction will undoubtedly bring about modifications in the properties of the BICUVOX.10/3Y-TZP junction, the more deleterious effect observed was the low electrical conductivity of the reaction products. For the 50B/50Z3 sample, which represents the reaction zone, electrical conductivity was five times smaller than that of BICUVOX.10. This effect demonstrates that when $\mathrm{YVO}_{4}$ formation and $\mathrm{ZrO}_{2}$ destabilization occur, the reacted layer in the contact region between BICUVOX.10 and YSZ will act hindering any catalytic effect initially expected by using BICUVOX.10 as a composite cathode. Indeed, this tendency to reaction might be reduced if low temperature adhesion techniques were

\section{References}

1. Steele BCH. Appraisal of $\mathrm{Ce} 1-\mathrm{yGdyO} 2-\mathrm{y} / 2$ electrolytes for IT-SOFC operation at $500{ }^{\circ} \mathrm{C}$. Solid State Ionics. 2000; 129(14):95-110. http://dx.doi.org/10.1016/S0167-2738(99)00319-7.

2. Steele $\mathrm{BCH}$, Hori $\mathrm{KM}$ and Uchino S. Kinetic parameters influencing the performance of IT-SOFC composite electrodes. Solid State Ionics. 2000; 135(1-4):445-450. http://dx.doi. org/10.1016/S0167-2738(00)00393-3.

3. Perry Murray E and Barnett SA. (La,Sr)MnO3-(Ce,Gd) $\mathrm{O} 2-\mathrm{x}$ composite cathodes for solid oxide fuel cells. Solid State Ionics. 2001; 143(3-4):265-273. http://dx.doi.org/10.1016/ S0167-2738(01)00871-2.

4. Xia C and Liu M. Novel cathodes for low-temperature solid oxide fuel cells. Advanced Materials. 2002; 14(7):521-523. http:// dx.doi.org/10.1002/1521-4095(20020404)14:7<521::AIDADMA521>3.0.CO;2-C.

5. Abrahams I and Krok F. A model for the mechanism of low temperature ionic conduction in divalent-substituted $\gamma$-BIMEVOXes. Solid State Ionics. 2003; 157(1-4):139-145. http://dx.doi.org/10.1016/S0167-2738(02)00201-1.

6. Nimat RK, Joshi RS and Pawar SH. Substrate dependent structural and electrical properties of $\mathrm{Bi} 2 \mathrm{Cu} 0.1 \mathrm{~V} 0.9 \mathrm{O} 5.35$ solid electrolyte thin films. Journal of Alloys and Compounds. 2008; 466(1-2):341-351. http://dx.doi.org/10.1016/j. jallcom.2007.11.051.

7. Paydar MH, Hadian AM, Shimanoe K and Yamazoe N. Microstructure, mechanical properties and ionic conductivity of BICUVOX - $\mathrm{ZrO} 2$ composite solid electrolytes. Journal employed. Nevertheless, finding a temperature which allows good adhesion and avoids reactions in BICUVOX.10-based cathodes is still a topic of current research ${ }^{10}$.

\section{Conclusions}

Reactions between BICUVOX.10 and YSZ were investigated and reported in this paper. Developing samples consisting of cathode and electrolyte materials in equal parts has shown to be a useful tool to characterize the reactions in the cathode/electrolyte interface. When BICUVOX.10 reacts with YSZ, the high temperature $\mathrm{ZrO}_{2}$ polymorphs - tetragonal and cubic - are destabilized to monoclinic. In addition, an $\mathrm{YVO}_{4}$ phase nucleates, a phenomenon which was attributed to the $\mathrm{V}^{5+}$ cation diffusion into the stabilized- $\mathrm{ZrO}_{2}$ lattice. Furthermore, these products have shown to be detrimental to the junction, since they lead to the deterioration of the electrolyte mechanical strength and to low electrical conductivity. In short, the application of BICUVOX.10 as highly catalytic component in the composite cathode used in yttria-stabilized zirconia electrolytes is restricted since both $\mathrm{YVO}_{4}$ formation and $\mathrm{ZrO}_{2}$ destabilization lead to poor properties of the junction.

\section{Acknowledgments}

The authors acknowledge the CNPq (project 131239/2012-0) and CAPES for the financial support provided for this research.

of Materials Science. 2002; 37(11):2273-2278. http://dx.doi. org/10.1023/A:1015321417272.

8. Xia C, Chen F and Liu M. Reduced-Temperature Solid Oxide Fuel Cells Fabricated by Screen Printing. Electrochemical and Solid-State Letters. 2001; 4(5):A52-A54. http://dx.doi. org/10.1149/1.1361158.

9. Xia C and Liu M. Low-temperature SOFCs based on Gd0.1Ce0.9O1.95 fabricated by dry pressing. Solid State Ionics. 2001; 144(3-4):249-255. http://dx.doi.org/10.1016/ S0167-2738(01)00980-8.

10. Samson AJ, Søgaard M and Bonanos N. Electrochemical characterization of infiltrated Bi2V0.9Cu0.1O5.35 cathodes for use in low temperature solid oxide fuel cells. Solid State Ionics. 2012; 211:74-79. http://dx.doi.org/10.1016/j.ssi.2012.01.027.

11. Shao Z, Mederos J, Kwak C and Haile SM. Evaluation of Bi2V0.9Cu0.1O5.35-an aurivillius-type conducting oxideas a cathode material for single-chamber solid-oxide fuel cells. Journal of Fuel Cell Science and Technology. 2010; 7(2):021016. http://dx.doi.org/10.1115/1.3182729.

12. Biz H. Synthesis, processing and characterization of BIMEVOX type ceramics. [Tese]. São Carlos: Federal University of São Carlos; 2000.

13. Bonanos N, Slotwinski RK, Steele BCH and Butler EP. High ionic conductivity in polycrystalline tetragonal $\mathrm{Y} 2 \mathrm{O} 3-\mathrm{ZrO} 2$. Journal of Materials Science Letters. 1984; 3(3):245-248. http://dx.doi.org/10.1007/BF00726805.

14. Kim BK, Hahn JW and Han KR. Quantitative phase analysis in tetragonal-rich tetragonal/monoclinic two phase zirconia by 
Raman spectroscopy. Journal of Materials Science Letters. 1997; 16(8):669-671. http://dx.doi.org/10.1023/A:1018587821260.

15. Es-Saheb MH, Albedah A and Benyahia F. Diametral compression test: validation using finite element analysis. International Journal of Advanced Manufacturing Technology. 2011; 57(5-8):501-509. http://dx.doi.org/10.1007/s00170-0113328-0.

16. Jones RL. Some aspects of the hot corrosion of thermal barrier coatings. Journal of Thermal Spray Technology. 1997; 6(1):7784. http://dx.doi.org/10.1007/BF02646315.

17. Afrasiabi A, Saremi M and Kobayashi A. A comparative study on hot corrosion resistance of three types of thermal barrier coatings: YSZ, YSZ + $\mathrm{A} 12 \mathrm{O} 3$ and YSZ/A12O3. Materials Science and Engineering: A. 2008; 478(1-2):264-269. http:// dx.doi.org/10.1016/j.msea.2007.06.001.

18. Herlt W. Vanadia reactions with yttria stabilized zirconia. Journal of Applied Physics. 1988; 63(11):5514-5520. http:// dx.doi.org/10.1063/1.340327.
19. Guo X. Effect of Nb2O5 on the space-charge conduction of Y2O3-stabilized ZrO2. Solid State Ionics. 1997; 99(1-2):137142. http://dx.doi.org/10.1016/S0167-2738(97)00147-1.

20. Yang SY, Lee JH, Kim JJ and Lee JS. Sintering behavior of Y-doped ZrO2 ceramics: the effect of $\mathrm{Al} 2 \mathrm{O} 3$ and $\mathrm{Nb} 2 \mathrm{O} 5$ addition. Solid State Ionics. 2004; 172(1-4):413-416. http:// dx.doi.org/10.1016/j.ssi.2004.03.026.

21. Guo X. Effect of DC voltage on the microstructure and electrical properties of stabilized-zirconia. Solid State Ionics. 1997; 99(1-2):143-151. http://dx.doi.org/10.1016/S01672738(97)00191-4.

22. Bogicevic A, Wolverton C, Crosbie GM and Stechel EB. Defect ordering in aliovalently doped cubic zirconia from first principles. Physical Review B: Condensed Matter and Materials Physics. 2001; 64(1):014106. http://dx.doi. org/10.1103/PhysRevB.64.014106.

23. Lee CK, Sinclair DC and West AR. Stoichiometry and stability of bismuth vanadate, Bi4V2O11, solid solutions. Solid State lonics. 1993; 62(3-4):193-198. http://dx.doi.org/10.1016/01672738(93)90372-A 